\title{
Comparative proteomic profiles of Aspergillus fumigatus and Aspergillus lentulus strains by surface-enhanced laser desorption ionization time-of-flight mass spectrometry (SELDI-TOF-MS)
}

Claudine Pinel ${ }^{1,2^{*}}$, Marie Arlotto ${ }^{1}$, Jean-Paul Issartel ${ }^{1}$, François Berger ${ }^{1}$, Hervé Pelloux ${ }^{2}$, Renée Grillot ${ }^{2}$ and Françoise Symoens ${ }^{3}$

\begin{abstract}
Background: Surface-enhanced laser desorption ionization time-of-flight mass spectrometry (SELDI-TOF-MS) was applied to analyze the protein profiles in both somatic and metabolic extracts of Aspergillus species. The study was carried out on some Aspergillus species within the Fumigati section (Aspergillus fumigatus wild-types and natural abnormally pigmented mutants, and Aspergillus lentulus). The aim was to validate whether mass spectrometry protein profiles can be used as specific signatures to discriminate different Aspergillus species or even mutants within the same species.

Results: The growth conditions and the SELDI-TOF parameters were determined to generate characteristic protein profiles of somatic and metabolic extracts of Aspergillus fumigatus strains using five different ProteinChips ${ }^{\circledR}$, eight growth conditions combining two temperatures, two media and two oxygenation conditions. Nine strains were investigated: three wild-types and four natural abnormally pigmented mutant strains of A. fumigatus and two strains of A. lentulus. A total of 242 fungal extracts were prepared. The spectra obtained are protein signatures linked to the physiological states of fungal strains depending on culture conditions. The best resolutions were obtained using the chromatographic surfaces CM10, NP20 and H50 with fractions of fungi grown on modified Sabouraud medium at $37^{\circ} \mathrm{C}$ in static condition. Under these conditions, the SELDI-TOF analysis allowed A. fumigatus and A. lentulus strains to be grouped into distinct clusters.
\end{abstract}

Conclusions: SELDI-TOF analysis distinguishes A. fumigatus from A. lentulus strains and moreover, permits separate clusters of natural abnormally pigmented $A$. fumigatus strains to be obtained. In addition, this methodology allowed us to point out fungal components specifically produced by a wild-type strain or natural mutants. It offers attractive potential for further studies of the Aspergillus biology or pathogenesis.

Keywords: SELDI-TOF mass spectrometry, ProteinChips ${ }^{\oplus}$, Aspergillus fumigatus, Aspergillus lentulus, proteomic analysis

\footnotetext{
* Correspondence: CPinel@chu-grenoble.fr

'Institut de Neurosciences « Plateforme de Transcriptomique et de

Protéomique Cliniques », (INSERM U836), Université Joseph Fourier, rue de la

Chantourne, Grenoble, 38043, France

Full list of author information is available at the end of the article
} 


\section{Background}

Aspergillus species comprise strains of medical and industrial importance. Only twenty out of the 250 species of the Aspergillus genus were isolated from patients with fungal diseases. Among them, A. fumigatus is the most important airborne fungal pathogen involved in various forms of aspergillosis in humans and animals [1-3]. Infections caused by this opportunistic and ubiquitous fungus can lead to fatal invasive aspergillosis in immunocompromised hosts with neutrophil deficiencies [4]. Its potential virulence is still poorly understood but it is probably associated with multiple and specific fungal factors, (among which its thermotolerance), in combination with host factors [5]. Recently, A. lentulus a species closely related to $A$. fumigatus within the Fumigati section, has been described by Balajee et al. [6]. This species has been associated with the same pathologies [7]. Moreover, it is naturally resistant to several antifungal drugs $[8,9]$.

The availability of a sequenced and annoted genome of $A$. fumigatus provided a new starting point to understand the biology of this medically important fungus [10]. So far, few studies have been published about the proteomics and modification of protein expression under different environmental conditions. The techniques used are essentially based on two-dimensional electrophoresis (2DE) which allows the detection and then the purification of fungal compounds for further identification. However, even after optimization, this method is time-and sample-consuming $[11,12]$. More recently matrix-assisted laser desorption ionization time of flight mass spectrometry (MALDI-TOF-MS) which associates sensitivity and efficacy, has been applied to analyze the protein composition of fungal proteome [13-18]. This methodology proved useful for unambiguous identification of Aspergillus and Penicillium species $[15,16]$. Another mass spectrometry approach, the surfaceenhanced laser desorption ionization time-of-flight mass spectrometry (SELDI-TOF-MS) has not yet been applied to detect fungal markers. This method provides specific advantages over conventional MALDI-TOF approaches as it combines chromatography on plane surfaces and mass spectrometry. SELDI-TOF-MS is specifically useful for comparative studies of selected components. The selective protein retention on the different target surfaces of the ProteinChips ${ }^{\mathbb{R}}$ arrays allows the rapid analysis of complex mixtures. Since its first description [19], the SELDI-TOF-MS method has been widely used to find specific markers in cancerous, cardiovascular, neurological and infectious diseases [20-27]. The SELDITOF technology also proved successful to allow the identification of a post translational modified form of vimentin that discriminates infiltrative and non infiltrative meningiomas [28]. In microbiology, SELDI-TOF-
MS was applied on Acidithiobacillus ferrooxidans [29] in order to better understand the physiological responses and biological adaptation of this pathogen to environmental conditions. In parasitological research, it was also applied to study the biological disturbances and detection of diagnostic markers in African trypanosomiasis $[30,31]$.

The strategy of protein expression profiling allows the selection of proteins of interest or specific biomarkers and gives information on the best way to purify and further characterize them. Indeed, the best suited chromatographic material and the proper elution conditions to use for purification of the proteins of interest can be predicted from the binding behavior of the protein detected on the ProteinChip ${ }^{\mathbb{B}}$ arrays. This technique like MALDI-TOF requires a minimal amount of proteins and is really appropriate for high throughput screening, particularly to distinguish up and down regulated proteins.

The aim of the present study, after selection of the culture conditions, was to assess the reliability of SELDI-TOF-MS method to analyze and discriminate crude fungal extracts (both somatic and metabolic fractions) of A. fumigatus and A. lentulus. It was also applied to discriminate natural abnormally pigmented mutant strains from a reference strain of A. fumigatus (strain used for annotation of the genome).

\section{Results and discussion}

\section{Optimization of the SELDI-TOF parameters}

(ProteinChips ${ }^{\circledR}$, amount of protein, storage of extracts, reproducibility)

Among the different ProteinChips ${ }^{\circledR}$ tested: CM10, NP20, $\mathrm{H} 50, \mathrm{Q} 10, \mathrm{IMAC} 30-\mathrm{Zn}_{2}$ and IMAC30-Cu $\mathrm{Cu}_{2}$, only CM10, NP20 and H50 chips were suitable. Binding of fungal components to the other ProteinChips ${ }^{\circledR}$ was too weak to allow efficient profile analysis.

The total amount of proteins spotted on the different ProteinChips ${ }^{\circledR}$ giving the best peaks resolution was $5 \mu \mathrm{g}$ on CM10 and H50 surfaces and $2 \mu \mathrm{g}$ on NP20 chip. Each preparation was analysed in duplicate on the ProteinChips ${ }^{\circledR}$. The spectra obtained from the culture media alone used as negative controls (concentrated modified Sabouraud and Czapeck media both without fungal cultures) did not interfere with the fungal protein spectra as the backgrounds were very low, few peaks of very low intensity were detected only under $4 \mathrm{kDa}$ (Figure 1A).

Sample storage at $-20^{\circ} \mathrm{C}$ did not alter the protein profiles (Figure 1B, C). However, as expected but never previously published to our knowledge for fungal extracts, the degradation was noticeable if the sample was stored at $4^{\circ} \mathrm{C}$ for seven days (Figure 1D). As numerous fungal proteins are proteolytic enzymes, the sample preparation 


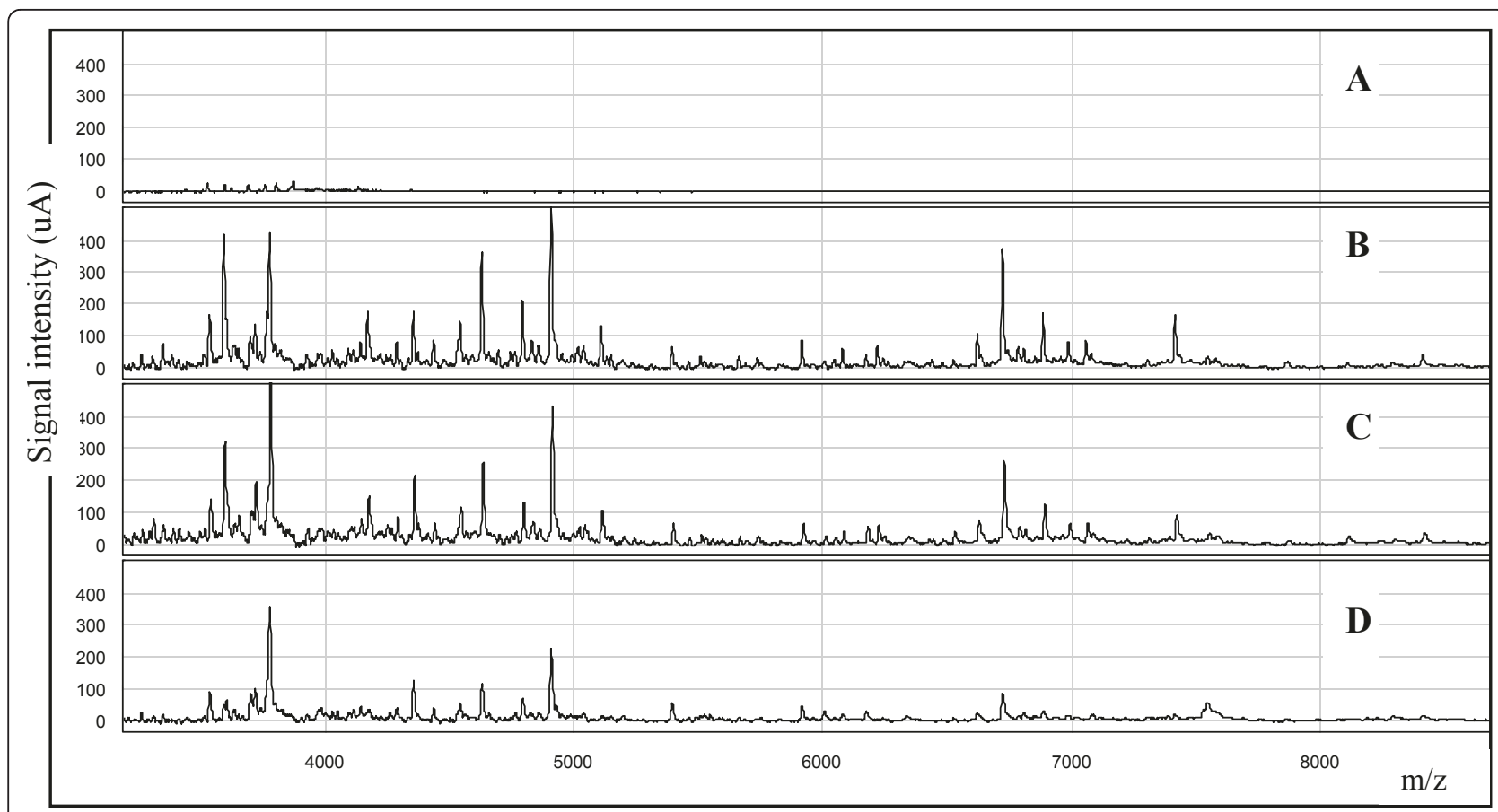

Figure 1 SELDI-TOF spectra on CM10 ProteinChips ${ }^{\circledR}$ of somatic extract of wild-type $A$. fumigatus (strain IHEM 22145) grown at $37^{\circ} \mathrm{C}$ on modified Czapeck medium. (A) Profile of the negative control (medium without fungal culture); (B) Fungal extract analysed immediately after preparation; (C) Profile of the same fraction analysed, in the same conditions, after storage at $-20^{\circ} \mathrm{C}$ for seven days; (D) Profile of the same extract analysed in the same conditions, after storage at $4^{\circ} \mathrm{C}$ for seven days.

and the storage conditions were of great importance in comparative studies. A strictly well defined protocol for the preparation and the rapid freezing at $-20^{\circ} \mathrm{C}$ of the extracts are essential to preserve native proteins [32]. Due to the absence of protease inhibitors, proteolysis may occur during sample preparation. However, in the conditions used to preserve the fungal proteins, we argued that the possible degradation could be homogenous in all samples and altered slightly the comparative studies. The coefficient of variation of peak profiles on CM10 evaluated on three extracts from simultaneous cultures reached an average of $14.2 \%$, lower reproducibility was obtained on NP20 (24.6\%) and on H50 (35.4\%).

\section{Selection of culture parameters: type of fractions, temperature, medium, oxygenation}

In order to select the culture conditions giving an abundance of fungal components qualitatively detected on chromatographic ProteinChips ${ }^{\circledR}$, we analyzed the somatic and metabolic protein patterns on NP20 and CM10 ProteinChips ${ }^{\circledR}$ of the three wild-types strains of A. fumigatus (IHEM 9599, IHEM 18963 and IHEM 22145) using eight culture conditions (two temperatures: $25^{\circ} \mathrm{C}$ and $37^{\circ} \mathrm{C}$, two oxygenation conditions: stationary and shaken culture, two media: modified Sabouraud and Czapek). Static and shaken fungal cultures were incubated at $37^{\circ} \mathrm{C}$ for four days and at $25^{\circ} \mathrm{C}$ for seven days.

\section{Somatic and metabolic extracts}

In the metabolic fractions, the total amount of proteins was at least three times as low as in the somatic fractions. Thus in the secretome (metabolic fractions), specific proteins in low abundance should be undetected in the mixture of the two types of extracts [33]. All fungal extracts from somatic and metabolic fractions obtained from the three wild-types strains of A. fumigatus were classified into two distinct clusters, whatever the growth conditions used (data not shown). As expected, this result highlights differences in protein profiles between these two types of extracts.

\section{Temperature, oxygenation and medium}

We observed great variations of protein patterns under various environmental conditions with the samples from the three wild-types strains of $A$. fumigatus. The number of significant differences $(\mathrm{p}<0.05)$ in protein profiles according to growth conditions used were important depending on temperature. In our observations, these differences decreased with oxygenation and medium respectively.

\section{Temperature}

The metabolic and somatic fractions from the three strains were separated into two distinct clusters according to growth temperature. Temperature modified the protein expressions in the same way for the three strains examined. Upregulated proteins were $60 \%$ higher at $37^{\circ}$ 
$\mathrm{C}$ versus $25^{\circ} \mathrm{C}$ in both metabolic and somatic extracts (Figures $2 \mathrm{~A}$ and $2 \mathrm{~B}$ ). In our conditions, twenty proteins were shown to be overexpressed at $37^{\circ} \mathrm{C}$ versus $25^{\circ} \mathrm{C}$ from the three wild-types strains of $A$. fumigatus strains. Protein overexpression at $37^{\circ} \mathrm{C}$, also documented in our study, has already been pointed out. Some overexpressed proteins have been supposed to be involved in $\mathrm{A}$. fumigatus virulence [34]. Essential genes for growth at $37^{\circ} \mathrm{C}$ have already been identified, and have been shown to play an important role in A. fumigatus survival and dissemination during invasive aspergillosis [35,36].

\section{Oxygenation}

On CM10 and NP20 ProteinChips ${ }^{\circledR}$, two distinct clusters were obtained depending on oxygenation conditions for all the fungal samples analyzed whatever the temperature and media applied to growth conditions (data not shown).

Oxygen and a functional respiratory chain have been demonstrated to be essential for the germination process and mycelial development of A. fumigatus [37]. The protein patterns for both the metabolic and somatic fractions are notably influenced by oxygenation. From cultures with modified Sabouraud medium at $37^{\circ} \mathrm{C}$, we observed 65 significant peaks out of 122 between static and shaken cultures for the somatic A. fumigatus extracts and 55 out of 112 for the metabolic fractions (p $<0.05$ ) (data not shown). Aspergillus fumigatus is exposed to rapid changes in hypoxic conditions at sites

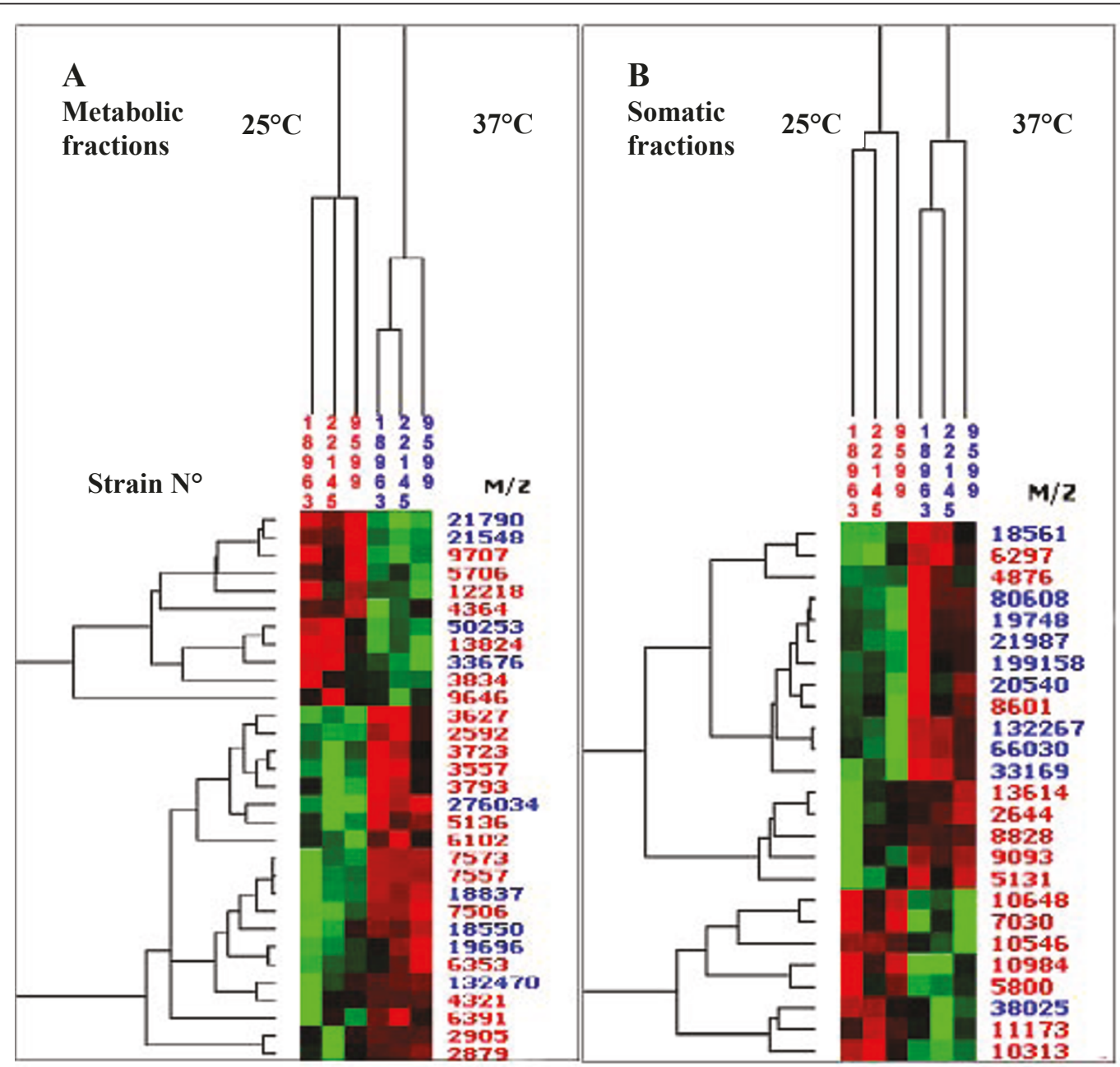

Figure 2 Proteomic analysis of the temperature effects. The hierarchical clustering obtained on CM10 ProteinChips ${ }^{\circledR}$ with metabolic extracts (A) and somatic extracts (B) with the three wild-type A. fumigatus strains (IHEM 18963, IHEM 22145, IHEM 9599). The three extracts, one for each strain, obtained at $25^{\circ} \mathrm{C}$ (in red) and at $37^{\circ} \mathrm{C}$ (in blue) are indicated on the top of the figure. Values on the right indicate the molecular mass of protein differentially expressed according to the laser intensities used (in red 2000 nanoJoule (nJ) and in blue 4000 nJ). Two clusters were observed according to growth temperatures with the metabolic and the somatic extracts. Higher number of proteins was up regulated at $37^{\circ} \mathrm{C}$ than at $25^{\circ} \mathrm{C}$ in both fractions. In the dendrograms shown, the red, black or green colour indicates that the relative intensity of the protein concentration is respectively higher, intermediate or lower than the mean value. 
of inflammation. The response to stressful conditions is likely to be an important virulence attribute of this pathogenic mold [5,38].

\section{Medium}

On modified Sabouraud medium the number of upregulated proteins was higher than in the modified Czapeck medium for the three wild-types strains of $A$. fumigatus. The medium composition obviously acts on fungal growth. The medium influence has already been shown using 2-D electrophoresis for A. fumigatus [12] and MALDI-TOF analysis for $A$. oryzae [39].

In conclusion, the results obtained clearly show that A. fumigatus proteome is dynamic and will adapt to its immediate environment as described for Aspergillus nidulans [40] and bacteria [41]. The three strains of $A$. fumigatus responded in the same way according to the variations of environmental factors such as temperature, medium and oxygenation. For comparative analysis applied to discriminate strains and species, the modified Sabouraud medium and incubation temperature at $37^{\circ} \mathrm{C}$ were selected.

\section{Comparison of atypical pigmented $A$. fumigatus strains versus a wild reference strain}

Fewer fungal proteins were retained on H50 ProteinChips ${ }^{\circledR}$. As pigmented structures and fungal surface layer consist mainly of hydrophobic proteins [42], H50 ProteinChip ${ }^{\circledR}$ was chosen in association with CM10 to compare the profiles obtained from one reference wild-type strain of $A$. fumigatus (IHEM 18963/Af 293) and four abnormally pigmented strains: three white strains (IHEM 2508, IHEM 9860 and IHEM 13262) and one brown strain (IHEM 15998). Fungal extracts were obtained from three sets of cultures started simultaneously and one set started another day. These cultures were performed on modified Sabouraud medium at $37^{\circ} \mathrm{C}$. Since pigments are produced during conidia formation (static culture), we maintained the two oxygenation conditions allowing the analysis of proteins from hyphae and conidia (static culture) and from hyphae (shaken culture).

A previous study on these strains [42] has shown that for two of the three white mutants investigated, the $A L B 1$ gene involved early in the melanin synthesis steps has mutated. For the brown mutant, a point mutation in the ARP2 gene involved in a later step of the melanin synthesis has been observed. These three strains presented white or brown powdery colonies. For the strain IHEM 13262, we observed poor conidiation and velvety colonies.

As previously observed with the three wild-type strains, the software classified $100 \%$ of the metabolic and somatic samples into two clusters in function of oxygenation conditions with the two types of ProteinChips ${ }^{(B)}$ used (CM10 and H50).
Furthermore, the SELDI-TOF-MS analysis of metabolic extracts obtained from static cultures performed on CM10 and on H50 ProteinChips ${ }^{\circledR}$ resulted in the classification of the five $A$. fumigatus strains (wild-types and mutants) in five clusters. Figure 3 illustrates the discrimination of the metabolic fractions obtained in static culture from the five strains on CM10 ProteinChip ${ }^{\circledR}$. Using this ProteinChip ${ }^{\circledR}$ with the five strains under study, eighteen proteins obtained from the metabolic fractions (shaken and static cultures) and thirteen from the somatic extracts (shaken and static cultures) expressed differently $(\mathrm{p}<0.05)$. Some of them were specifically found in the extracts from the wild-type strain in the metabolic and in somatic fractions. On H50 surfaces, only twelve proteins expressed in significantly different ways in the 2 types of extracts.

An example of differentially expressed proteins found is illustrated in Figures $4 \mathrm{~A}$ and $4 \mathrm{~B}$ with the CM10 ProteinChips ${ }^{\circledR}$. A protein with a molecular mass of around $7000 \mathrm{Da}$ was detected in the somatic extracts from the wild-type strain with both ProteinChips ${ }^{\circledR}$ used ( $\mathrm{p}<$ 0.021) but not in the extracts obtained from the four abnormally pigmented $A$. fumigatus strains (Figure $4 \mathrm{~A}$ ). On the contrary, a protein with a molecular mass of around 8530 Da was found to be secreted by all four mutants in metabolic fractions from static cultures where pigment and conidia were developed $(\mathrm{p}<0.039)$ but was not detected in metabolic fractions obtained from the wild-type strain as shown in Figure $4 \mathrm{~B}$. Its relation to pigmentation or induction or repression of other genes remains to be established.

The SELDI-TOF comparison of these four natural mutants with the wild-type reference strain is powerful. This analysis indicated protein masses of interest which could open further investigations in the comparative study between mutants and wild-type strains. As observed, this method is highly suitable to separate low molecular weight compounds and could provide complementary data to other analytical techniques [43]. Thus, as described for bacteria [25], this method may be also suitable to discriminate isolates within the same species.

\section{Comparison of $A$. fumigatus and $A$. lentulus extracts}

In addition to the separation of strains within the same species, we applied hierarchical clustering to differentiate $A$. fumigatus from $A$. lentulus, a closely related species from the Fumigati section, using CM10 and NP20 ProteinChips ${ }^{\circledR}$ chosen for to their good reproducibility. Metabolic extracts (from seven different sets of experiments: six grown simultaneously and one independently) from $A$. fumigatus and $A$. lentulus strains were classified into distinct clusters on CM10 (Figure 5) as well as on NP20 ProteinChips ${ }^{\circledR}$ (not shown). Ten out of 101 
extracts from the two A. lentulus strains were not completely separated (not shown). The best resolution was obtained with the metabolic samples on CM10 ProteinChip $^{\circledR}$, perfect distinction was obtained between the two species and between the two isolates within the same species (Figure 5).

Even if these two species are morphologically very similar, it has been shown that they display differences in their cell wall composition, i.e. A. lentulus contains less chitin than $A$. fumigatus [9], is less thermotolerant and produced different secondary metabolites. The conidium surface is smooth and lack hydrophobic rodlet layer. These biochemical and structural differences could explain a distinguishable protein pattern.

\section{Conclusions}

The qualitative and quantitative results provided by SELDI-TOF-MS can be obtained in a rapid, sensitive and reproducible way if careful and standardized procedures are used for sample preparation and storage. The spectra obtained on CM10 chip essentially are protein signatures representative of the strains and of their physiological states. The proteomic analysis allows the distinction of not only the closely related species $A$. fumigatus and $A$. lentulus but also natural mutants within the A. fumigatus species. Furthermore, it could be an analytical tool in the research of molecular mechanisms involved in the physiopathology of $A$. fumigatus. It could be also a powerful method for quality control of antigenic extracts for diagnosis purposes.

\section{Methods}

Fungal strains

All the strains detailed in Table 1 were referenced and preserved in the BCCM/IHEM Collection of the Scientific Institute of Public Health, Brussels, Belgium (http:// bccm.belspo.be/db/ihem_search_form.php). They consisted of three wild-type strains of $A$. fumigatus (WT), including strain Af 293 used for genome sequencing of A. fumigatus and four natural abnormally pigmented strains of A. fumigatus (M) among which one brown and three white strains. All the isolates were identified by macroscopic and microscopic morphology. Their identification was confirmed by internal transcribed spacers (ITS) regions of ribosomal DNA gene and by $\beta$ tubulin gene sequencing $[8,44]$. Two A. lentulus strains came from the CBS collection (Centraalbureau voor Schimmelcultures, Utrecht, The Netherlands).

\section{Culture conditions}

In order to optimize the growth condition for the characterization of protein extracts from $A$. fumigatus, eight culture conditions were selected: two temperatures corresponding to those used for sample cultures in medical tus extracts (Figure 5). Somatic extracts from the two Aspergillus species were also separated into two distinct clusters according to the species. However, the somatic 


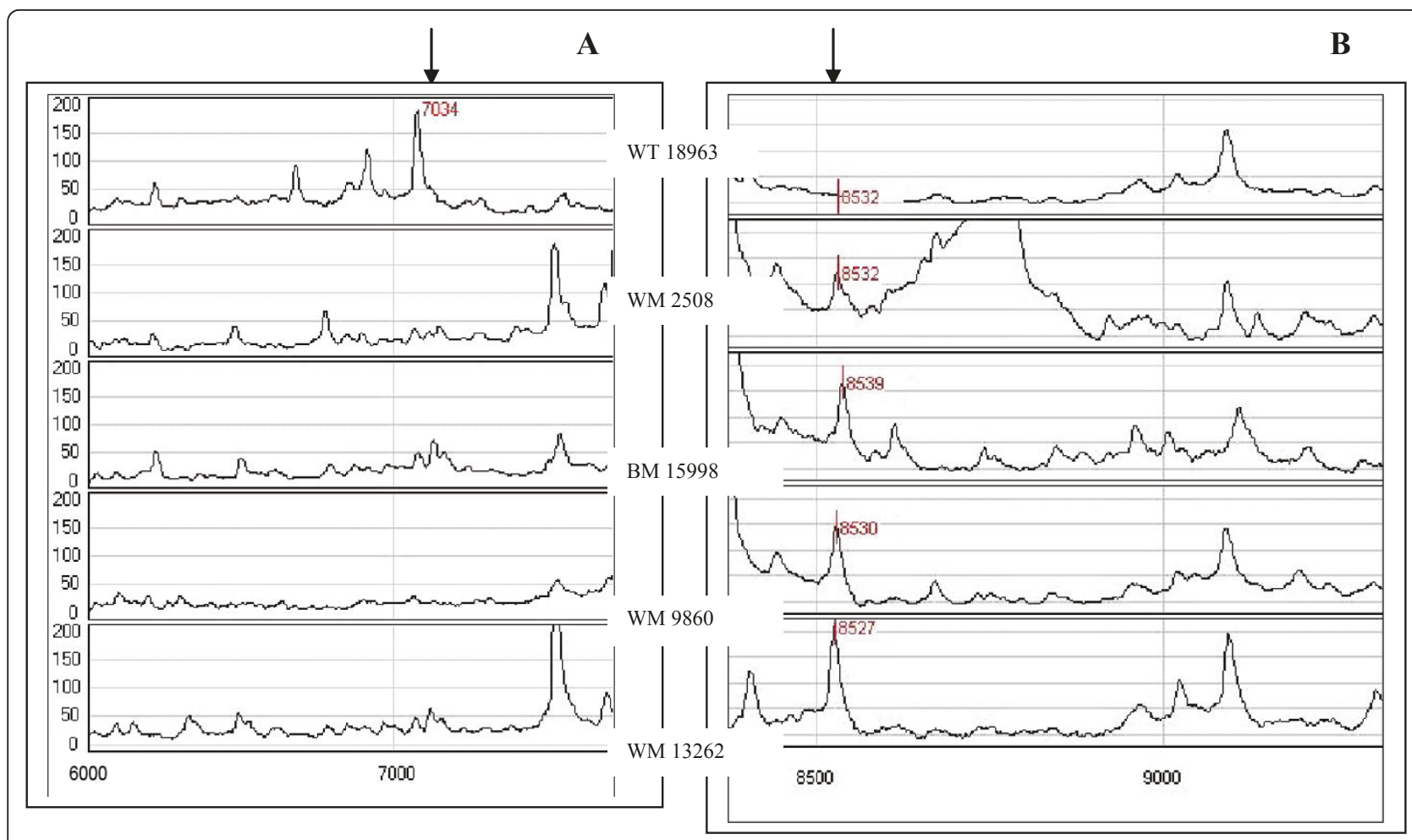

Figure 4 Examples of SELDI-TOF spectra of differentially expressed proteins on CM10 ProteinChips ${ }^{\circledR}$. A: The protein profile showed a protein of $7034 \mathrm{Da}$ mostly expressed by the wild-type strain in the somatic fraction obtained from shaken culture, B: A peak around $8530 \mathrm{Da}$ was detected only in the metabolic fractions obtained from static cultures of the four abnormally pigmented A. fumigatus strains (IHEM 2508, 15998, 9860 and 13262). WT: wild-type, WM: White mutant, BM: Brown mutant.

mycology $\left(25^{\circ} \mathrm{C}\right.$ and $\left.37^{\circ} \mathrm{C}\right)$, two media (modified Sabouraud and modified Czapeck), and two oxygenation conditions (static and shaken cultures). Modified Sabouraud medium consisted of dextrose $20 \mathrm{~g} / \mathrm{l}$, neopeptone $10 \mathrm{~g} / \mathrm{l}$, $\mathrm{MgSO}_{4} 0.5 \mathrm{~g} / \mathrm{l}, \mathrm{KH}_{2} \mathrm{PO}_{4} 0.5 \mathrm{~g} / \mathrm{l}$, oligoelements solution $1 \mathrm{ml}$ of the following solution: $\mathrm{H}_{3} \mathrm{BO}_{3} 58 \mathrm{mg} / \mathrm{l}, \mathrm{CuCl}_{2}$. $2 \mathrm{H}_{2} \mathrm{O} 270 \mathrm{mg} / \mathrm{l}, \mathrm{MnCl}_{2} \cdot 4 \mathrm{H}_{2} \mathrm{O} 78 \mathrm{mg} / \mathrm{l}, \mathrm{ZnCl}_{2} 4.2 \mathrm{mg} / \mathrm{l}$, $\mathrm{FeCl}_{2} .4 \mathrm{H}_{2} \mathrm{O} 3 \mathrm{mg} / \mathrm{l},\left(\mathrm{NH}_{4}\right)_{6} \mathrm{Mo}_{7} \mathrm{O}_{24} .4 \mathrm{H}_{2} \mathrm{O} 0.2 \%$. Modified Czapek medium consisted of saccharose $15 \mathrm{~g} / \mathrm{l}$, yeast nitrogen base $1 \mathrm{~g} / \mathrm{l}$, brain heart $1 \mathrm{~g} / \mathrm{l}, \mathrm{NaNO}_{3} 3 \mathrm{~g} / \mathrm{l}$, $\mathrm{K}_{2} \mathrm{HPO}_{4} 1 \mathrm{~g} / \mathrm{l}, \mathrm{KCl} 0.5 \mathrm{~g} / \mathrm{l}, \mathrm{MgSO}_{4} 0.5 \mathrm{~g} / \mathrm{l}, \mathrm{FeSO}_{4} .7 \mathrm{H}_{2} \mathrm{O}$ $0.01 \mathrm{~g} / \mathrm{l})$. Both media were home-made. The strains were grown at $25^{\circ} \mathrm{C}$ for seven days and at $37^{\circ} \mathrm{C}$ for four days. The oxygenation conditions corresponded to static culture (Roux Flasks) and to shaken culture (gyratory shaker at $150 \mathrm{rpm})$.

\section{Preparation of fungal protein extracts}

Fungal mycelium and conidia were collected from Roux flask and filtered on a folded Whatman filter (Schleicher \& Schuell 10311853). Shaken cultures were also filtered in the same conditions to separate growth medium from mycelium.

Somatic proteins were mechanically extracted from the fungus mycelium with Ultraturrax in $\mathrm{NH}_{4} \mathrm{HCO}_{3}$ buffer $0.4 \%$, shaken overnight at $4{ }^{\circ} \mathrm{C}$ and centrifuged at 10000 g. The supernatant was concentrated with Amicon Ultra UFC900324 (Millipore, USA). The amount of protein was estimated by colorimetry (Biophotometer Eppendorf) using QuickStart Bradford Dye Reagent (Bio-Rad protein assay 500-0205) with Bovine Serum Albumin as standard (Bio-Rad 500-026). The average of protein fraction in the extracts was $60 \%$ to $70 \%$ (wt/wt).

The metabolic extracts were directly concentrated from the culture medium with Amicon Ultra. The extracts were freeze dried for long-term stability (freeze dryer Christ Epsilon 1D, Germany).

In order to assess the variability of the protein expression, the extracts from the strains listed in Table 1 were prepared from three cultures performed simultaneously and from two to four cultures performed at different days.

\section{SELDI-TOF-MS analysis}

To analyze the fungal spectra using SELDI-TOF-MS, the extracts were applied to weak cation exchange (CM10), normal silicate surface (NP20), reverse phase (H50), strong anion exchange $(\mathrm{Q} 10)$ and immobilized metal affinity capture (IMAC $30-\mathrm{Cu}_{2}$ or IMAC $30-\mathrm{Zn}_{2}$ ) ProteinChips ${ }^{\circledR}$ in 96-sample bioprocessors (Bio-Rad 


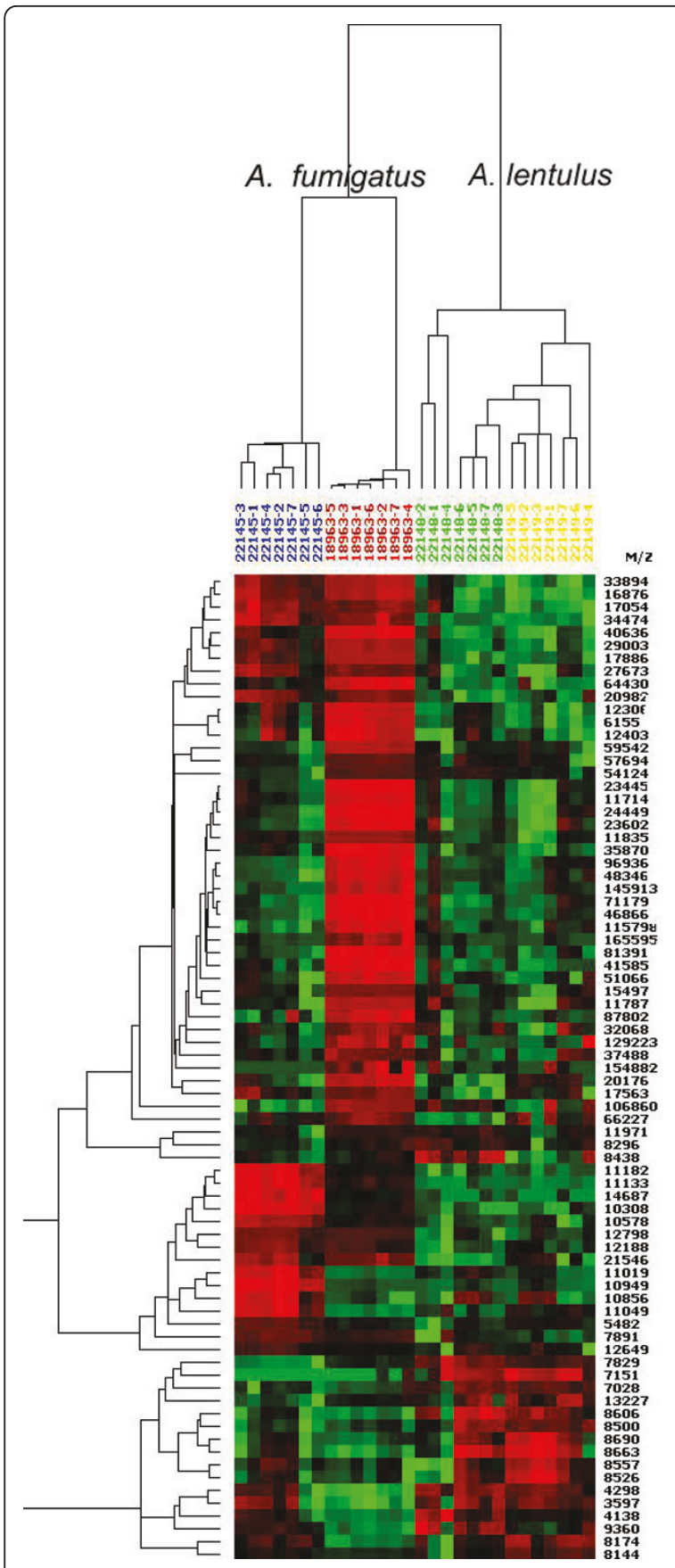

Figure 5 The hierarchical clustering of $A$. fumigatus and $A$. lentulus metabolic extracts. (shaken culture, modified Sabouraud medium at $37^{\circ} \mathrm{C}$, on $\mathrm{CM} 10$ ProteinChips ${ }^{\circledR}$ ) showing 77 out of 101 significant $p$ values $(p<0.01)$. From the right to the left: in red and blue colour A. fumigatus (strains IHEM 22145 and IHEM18963) and in green and yellow colour A. lentulus (strains IHEM 22148 and IHEM 22149).

Laboratories, Hercules, CA, USA). All these surfaces were tested in order to select those retaining a large number of fungal compounds with a good resolution. The ProteinChips ${ }^{\circledR}$ preparation, samples and matrix application were performed according to the manufacturer's instructions with slight modifications described below.

The freeze-dried samples were diluted with sterile distilled water in order to obtain $1 \mu \mathrm{g}$ of total protein $/ \mu \mathrm{L}$. To preserve proteins from enzymatic degradation, the dilutions were immediately stored at $-20^{\circ} \mathrm{C}$ until use. Five $\mu \mathrm{g}$ of sample were first diluted $(1 / 20)$ in binding buffer and loaded on CM10, Q10, H50 and IMAC30$\mathrm{Cu}_{2}$ or IMAC30- $\mathrm{Zn}_{2}$ ProteinChip then incubated for $1 \mathrm{hr}$ at room temperature. The unbound proteins were removed by washing three times with $200 \mu \mathrm{L}$ of the same buffer, the ProteinChips ${ }^{\circledR}$ were quickly rinsed with pure water and left to dry. For NP20 ProteinChips ${ }^{\circledR}, 2$ $\mu \mathrm{L}$ of sample were applied on the spot and left to dry, and then washed three times with $5 \mu \mathrm{L}$ of water. Matrix (100\% saturated solution of sinapinic acid in $0.5 \%$ trifluoroacetic acid $/ 50 \%$ acetonitrile) was applied to each spot (twice $0.8 \mu \mathrm{L}$ ). The absorbed proteins were then analyzed on a ProteinChip Reader (series 4000, Bio-Rad Laboratories, Hercules, CA, USA). Spectra were obtained using two different acquisition protocols, for low (2.5-14 kDa) and high (14-400 kDa) molecular mass proteins, respectively. External mass calibration was performed with ProteinChip All-in-One Protein Standard II (Bio-Rad, laboratories, Hercules, CA, USA). Peak annotation was performed after base-line subtraction, noise calculation, and normalization by total ion current (TIC). Peak detection was achieved with ProteinChip Data Manager Software and only peaks with a signal-tonoise ratio $>5$ were used for analysis (Bio-Rad Laboratories, Hercules, CA, USA).

\section{Statistical analysis}

Statistical analyses were performed using ProteinChip Data Manager 3.0 software (Bio-Rad Laboratories, Hercules, CA, USA). All the spectra were compiled, and qualified mass peaks (signal-to-noise ratio $>5$ ) with mass-to-charge ratio $(\mathrm{m} / \mathrm{z})$ between $2.5 \mathrm{kDa}$ and 250 $\mathrm{kDa}$ were auto detected. P-values were calculated using non parametric Mann-Whitney $U$-test, which tests the null hypothesis that the medians of the peak intensities of the groups are equal. A p-value less than 0.05 was accepted as statistically significant. The difference was also examined by hierarchical clustering.

\section{Acknowledgements and funding}

We gratefully thank Christel Binard and Sabine Durville for reading the manuscript and improving the English redaction.

This study was supported by the Belgian Science Policy Office (contract C3/ 00/19).

\section{Author details}

${ }^{1}$ Institut de Neurosciences «Plateforme de Transcriptomique et de

Protéomique Cliniques », (INSERM U836), Université Joseph Fourier, rue de la 
Table 1 References, characteristics and origin of the different Aspergillus fumigatus (Afu) and Aspergillus lentulus (Ale) strains used

\begin{tabular}{|c|c|c|c|c|c|}
\hline $\begin{array}{l}\text { IHEM } \\
\text { Number }\end{array}$ & $\begin{array}{l}\text { Other } \\
\text { acronym }\end{array}$ & $\begin{array}{l}\text { Species } \\
\text { Afu/Ale }\end{array}$ & $\begin{array}{l}\text { Strain } \\
\text { characteristics }\end{array}$ & $\begin{array}{l}\text { Substrate origin, underlying } \\
\text { disease }\end{array}$ & $\begin{array}{l}\text { Year isolation, } \\
\text { Country }\end{array}$ \\
\hline 9599 & & Afu & $W T^{*}$ & human blood culture, IA (hepatoblastoma), & 1995, France \\
\hline 22145 & & Afu & WT & Human cerebral biopsy, IA (leukaemia) & 2001, France \\
\hline 18963 & Af293 & Afu & WT & Human lung, IA (autopsy), reference sequencing project & 1993, UK \\
\hline 2508 & & Afu & White $M^{* *}$ & Hospital environment & 1985, Belgium \\
\hline 9860 & CBS 386.75 & Afu & White M & Usar soil & 1975, India \\
\hline 13262 & $\begin{array}{l}\text { CBS } 110.46 \\
=\text { ATCC } 16907\end{array}$ & Afu & White M & Type strain of helvola mutant & 1939 \\
\hline 15998 & & Afu & Brown M & Human sputum (cystic fibrosis) & 1999, France \\
\hline 22148 & CBS 175.97 & Ale & & Dolfin nostril & 1996, The Netherlands \\
\hline 22149 & CBS 116883 & Ale & & Soil & 2003, Korea \\
\hline
\end{tabular}

*WT: wild-type, ${ }^{* *} \mathrm{M}$ : mutant, IA: invasive aspergillosis.

Chantourne, Grenoble, 38043, France. '2Laboratoire de ParasitologieMycologie, Institut de Biologie et Pathologie (IBP), Centre Hospitalier Universitaire Albert Michallon, BP 217, Grenoble, 38043, France. ${ }^{3}$ Mycology \& Aerobiology Section, Scientific Institute of Public Health, 14 rue Juliette Wytsmanstreet, Brussels, 1050, Belgium.

\section{Authors' contributions}

CP conceived the project and drafted the manuscript, MA processed the samples and analysed SELDI-TOF data, JPI, RG, FB and HP were involved in interpretation and presentation of the results, FS prepared the Aspergillus samples and co-directed the project. All authors read, discussed and approved the final manuscript.

\section{Competing interests}

The authors declare that they have no competing interests.

Received: 15 February 2011 Accepted: 28 July 2011

Published: 28 July 2011

\section{References}

1. Latgé JP: Aspergillus fumigatus and aspergillosis. Clin Microbiol Rev 1999, 12:310-350.

2. Latgé JP: The pathobiology of Aspergillus fumigatus. Trends Microbiol 2001, 9:382-389.

3. Geiser DM, Klich MA, Frisvad JC, Peterson SW, Varga J, Samson RA: The current status of species recognition and identification of Aspergillus. Stud Mycol 2007, 59:1-10.

4. Hohl TB, Feldmesser M: Aspergillus fumigatus: principles of pathogenesis and host defense. Eukaryotic Cell 2007, 6:1953-1963.

5. Abad A, Fernandez-Molina JV, Bikandi J, Ramirez A, Margareto J, Sendino J, Hernando FL, Ponton J, Garaizar J, Rementeria A: What makes Aspergillus fumigatus a successful pathogen? Genes and molecules involved in invasive aspergillosis. Rev Iberoam Micol 2010, 27:155-182.

6. Balajee SA, Gribskov JL, Hanley E, Nickle D, Marr KA: Aspergillus lentulus sp. nov., a new sibling species of A. fumigatus. Eukaryot Cell 2005, 4:625-632.

7. Montenegro G, Puch S, Sanchez VM, Jewtuchowicz MV, Pinoni MV, Relloso S, Temporitti E, lovannatti CA, Mujica MT: Phenotypic and genotypic characterization of Aspergillus lentulus and Aspergillus fumigatus isolates in a patient with probable invasive aspergillosis. $J$ Med Microbiol 2009, 58:391-395.

8. Balajee SA, Nickle D, Varga J, Marr KA: Molecular studies reveal frequent misidentification of Aspergillus fumigatus by morphotyping. Eukaryot Cell 2006, 5:1705-1712.

9. Staab JF, Kahn JN, Marr KA: Differential Aspergillus lentulus echinocandin susceptibilities are Fksp-independent. Antimicrob Agents Chemother 2010, 54:4992-4998.

10. Nierman WC, Pain A, Anderson MJ, Wortman JR, Kim HS, Arroyo J, Berriman M, Abe K, Archer DB, Bermejo C, Bennett J, Bowyer P, Chen D, Collins M, Coulsen R, Davies R, Dyer PS, Farman M, Fedorova N, Fedorova N, Feldblyum TV, Fischer R, Fosker N, Fraser A, García JL, García MJ, Goble A,
Goldman GH, Gomi K, Griffith-Jones S, Gwilliam R, et al: Genomic sequences of the pathogenic and allergenic filamentous fungus Aspergillus fumigatus. Nature 2005, 438:1151-1156.

11. Shevchenko A, Jensen ON, Podtelejniko AV, Sagliocco F, Wilm M, Vorm O, Mortensen $\mathrm{P}$, Boucherie $\mathrm{H}$, Mann M: Linking genome and proteome by mass spectrometry: large scale identification of yeast proteins from two dimensional gels. Proc Natl Acad Sci USA 1996, 93:14440-14445.

12. Kniemeyer $O$, Lessing $F$, Scheibner $O$, Hertweck $C$, Brakhage $A A$ : Optimisation of a 2D electrophoresis protocol for the human pathogenic fungus Aspergillus fumigatus. Curr Genet 2006, 49:178-189.

13. Grinyer J, McKay M, Nevalainem $H$, Herbert BR: Fungal proteomics: initial mapping of biological control strain Trichoderma harzianum. Curr Genet 2004, 45:163-169.

14. Kim Y, Nandakumar MP, Marten MR: Proteomics of filamentous fungi. Trends in Biotechnology 2007, 25:395-400.

15. Hettick JM, Green BJ, Buskirk AD, Kashon ML, Slaven JE, Janotka E, Blachere FM, Schelchel D, Beezhold DH: Discrimination of Aspergillus isolates at the species and strain level by matrix-assisted laser desorption/ionization time-of-flight mass spectrometry fingerprinting. Anal Biochem 2008, 380:276-281.

16. Hettick JM, Green BJ, Buskirk AD, Kashon ML, Slaven JE, Janotka E, Blachere FM, Schmechel D, Beezhold DH: Discrimination of Penicillium isolates by matrixassisted laser desorption/ionization time-of-flight mass spectrometry fingerprintingy. Rapid Commun Mass Spectrom 2008, 22:2555-2560.

17. Kim Y, Nandakumar MP, Marten MR: The state of proteome profiling in the fungus genus Aspergillus. Brief Funct Genomic Proteomic 2008, 7:780-783

18. Marinach-Patrice C, Fekkar A, Atanasova R, Gomes J, Djamdjian L, Brossas JY, Meyer I, Buffet P, Snounbou G, Datry A, Hennequin C, Golmard JL, Mazier D: Rapid species diagnosis for invasive candidiasis using mass spectrometry. PloS One 2010, 5:e8862.

19. Hutchens TW, Yip TT: New desorption strategies for the mass spectrometry analysis of macromolecules. Rapid Commun Mass Spectrom 1993, 7:576-580.

20. Seibert V, Wiesner A, Buschmann T, Meuer J: Surface-enhanced laser desorption ionization time-of-flight mass spectrometry (SELDI TOF-MS) and ProteinChip technology in proteomic research. Pathol Res Pract 2004, 200:83-94.

21. Tang N, Tornatore $P$, Weinberger SR: Current developments in SELDI affinity technology. Mass Spectrometry Rev 2004, 23:34-44.

22. Poon TC, Hui AY, Chan HL, Ang IL, Chow SM, Wong N, Sung JJ: Prediction of liver fibrosis and cirrhosis in chronic hepatitis $B$ infection by serum proteomic fingerprinting: a pilot study. Clin Chem 2005, 51:328-335.

23. Engwegen JY, Gast A, Schellens JH, Beijnen JH: Clinical proteomics: searching for better tumour markers with SELDI-TOF mass spectrometry. Trends Pharmacol Sci 2006, 27:251-259.

24. Abromovitz M, Leyland-Jones B: A system approach to clinical oncology: focus on breast cancer. Proteome Sci 2006, 4:1-15.

25. Seibold E, Bogumil R, Vorderwürlbecke S, Al Dahouk S, Buckendhahl A, Tomaso H, Splettstoesser W: Optimized application of surface-enhanced 
laser desorption/ionization time-of-flight MS to differentiate Francisella tularensis at the level of subspecies and individual strains. FEMS Immunol Med Microbiol 2007, 49:364-373.

26. Gupta P, Lee KH: Genomics and proteomics in process development opportunities and challenges. Trends Biotechnol 2007, 25:324-330.

27. Hodgetts A, Levin M, Kroll JS, Langforgd PR: Biomarker discovery in infections diseases using SELDI. Future Microbiol 2007, 2:35-49.

28. Bouamrani A, Ramus C, Gay E, Pelletier L, Cubizolles M, Brugière S, Wion D, Berger F, Issartel JP: Increased phosphorylation of vimentin in noninfiltrative meningiomas. PLoS One 2010, 16:5e9238.

29. He Z, Zhong H, Hu Y, Xiao S, Xu J: Analysis of differential protein expression in Acidithiobacillus ferrooxidans grown under different energy resources respectively using SELDI-proteinChip technologies. J Microbiol Meth 2006, 65:10-20.

30. Stiles JK, Whittaker J, Sarfo BY, Thompson WE, Powell MD, Bond VC: Trypanosome apoptotic factors mediates apoptosis in human brain vascular endothelial cells. Mol Biochem Parasitol 2004, 133:229-240.

31. Agranoff D, Stich A, Abel P, Krishna S: Proteomic fingerprinting for the diagnosis of human African trypanosomiasis. Trends Parasitol 2005, 21:154-156.

32. Monod M, Jousson O, Utz R: Aspergillus fumigatus secreted proteases. In Aspergillus fumigatus and Aspergillosis. Edited by: JP Latgé, WJ Steinbach. ASM Press; 2009:87-106.

33. Hogan DA: Talking to themselves: autoregulation and quorum sensing in fungi. Eukaryot Cell 2006, 5:613-619.

34. Bhabhra R, Miley MD, Mylonakis E, Boettner D, Fortwendel J, Panepinto JC, Postow M, Rhodes JC, Askew DS: Disruption of the Aspergillus fumigatus gene encoding nucleolar protein CgrA impairs thermotolerant growth and reduces virulence. Infect Immun 2004, 72:4731-4740.

35. Shankar J, Nigam S, Saxena S, Madan T, Sarma PU: Identification and assignment of function to the genes of Aspergillus fumigatus expressed at $37^{\circ} \mathrm{C}$. J Eukaryot Microbiol 2004, 51:428-432.

36. Askew DS: Aspergillus virulence genes in a street-smart mold. Cur Opin Microbiol 2008, 11:331-337.

37. Taubitz A, Bauer B, Heeseman J, Ebel F: Role of respiration in the germination process of the pathogenic mould Aspergillus fumigatus. Curr Microbiol 2007, 54:354-360.

38. Willger SD, Puttikamonkul S, Kim SH, Burritt JB, Grahl N, Metzler LJ, Barbuch R, Bard M, Laurence CB, Cramer RA: A sterol-regulatory element binding protein is required for cell polarity, hypoxia adaptation, azole drug resistance and virulence in Aspergillus fumigatus. PloS Pathogens 2008, 4:e1000200.

39. Oda K, Kakizono D, Yamada O, lefuji H, Akita O, Iwashita K: Proteomic analysis of extracellular proteins from Aspergillus oryzae grown under submerged and solid state culture conditions. Appl Environ Microbiol 2006, 72:3448-3457.

40. Kim Y, Nandakumar MP, Marten MR: Proteome map of Aspergillus nidulans during osmoadaptation. Fungal Genet Biol 2007, 44:886-895.

41. Egan S, Lanigan M, Shiell B, Beddome G, Stewart D, Vaughan J, Michalski WP: The recovery of Mycobacterium avium subspecies paratuberculosis from the intestine of infected ruminants for proteomic evaluation. J Microbiol Meth 2008, 75:29-39.

42. Pihet $M$, Vandeputte $P$, Tronchin G, Renier G, Saulnier P, Georgeault $S$, Mallet R, Chabasse D, Symoens F, Bouchara JP: Melanin is an essential component for the integrity of the cell wall of Aspergillus fumigatus conidia. BMC Microbiol 2009, 9:177.

43. Kiehntopf M, Siegmund R, Deufel T: Use of SELDI-TOF mass spectrometry for identification of new biomarkers: potential and limitations. Clin Chem Lab Med 2007, 45:1435-1449.

44. Leaw SN, Chang HC, Sun HF, Barton R, Bouchara JP, Chang TC: Identification of medically important yeast species by sequence analysis of internal transcribed spacer regions. J Clin Microbiol 2006, 44:693-699.

doi:10.1186/1471-2180-11-172

Cite this article as: Pinel et al: Comparative proteomic profiles of Aspergillus fumigatus and Aspergillus lentulus strains by surfaceenhanced laser desorption ionization time-of-flight mass spectrometry (SELDI-TOF-MS). BMC Microbiology 2011 11:172.

\section{Submit your next manuscript to BioMed Central and take full advantage of:}

- Convenient online submission

- Thorough peer review

- No space constraints or color figure charges

- Immediate publication on acceptance

- Inclusion in PubMed, CAS, Scopus and Google Scholar

- Research which is freely available for redistribution 